\title{
Improved Syntheses of Aromatase Inhibitors and Neuroactive Steroids Efficient Oxidations and Reductions at Key Positions for Bioactivity
}

\author{
André S. Campos Neves, Maria Luisa Sá e Melo, Maria José S. M. Moreno, \\ Elisiário J. Tavares da Silva, Jorge A. R. Salvador, Saul P. da Costa, Rosa Maria L. M. Martins \\ Centro de Estudos Farmacêuticos, Lab. de Química Farmacêutica, Faculdade de Farmácia, Universidade de Coimbra, \\ 3000 Coimbra, Portugal
}

Received 19 May 1998; revised 27 July 1998; accepted 29 July 1998

\begin{abstract}
An Henbest reduction, followed by the preparation of a silyl enol ether and oxidation in situ with $m$-CPBA has led to the neurosteroids $3 \alpha$-hydroxy-and $3 \alpha, 21$-dihydroxy-5 $\alpha$-pregnanolones. Using testosterone as starting material, a new short synthesis of an aromatase inhibitor, 4-OHA, has been achieved through hydroboration/oxidation followed by a Swern type oxidation and epimerization. Another aromatase inhibitor, androst-4-ene-3,6,17-trione, has been efficiently prepared using PCC on montmorillonite K10, under ultrasonic irradiation. (1) 1999 Elsevier Science Ltd. All rights reserved.
\end{abstract}

\section{INTRODUCTION}

Steroids are an important class of biologically active compounds and a large number are used in therapy. ${ }^{\text {la,b }}$ Over the last 15 years the biochemistry of steroids has advanced very rapidly and such developments have been quite relevant for research of new drugs and led to a renewed interest in steroids.

At present, potent and selective inhibitors of steroid-converting enzymes are very promising to use in association with steroid anti-hormones or as replacements. The inhibition of aromatase, a cytochrome P-450 enzyme, ${ }^{2}$ is of special interest in cancer therapy for two reasons. First the production of estrogens has been associated with breast cancer. Secondly, since the enzyme aromatase is involved in the final biosynthetic step, its inhibitors are of greater therapeutic interest. ${ }^{3}$ Further, inhibition of aromatase has been suggested to be important in the treatment of other malignant diseases in aging. ${ }^{4}$

Recently researchers have provided a large body of evidence that supports the existence of a novel class of steroids which are devoid any known steroid hormone activity and have high specificity for the $\mathrm{GABA}_{\mathrm{A}}$ receptor complex (GRC), a ligand-gated chloride channel that mediates the inhibitory action of the neurotransmiter $\gamma$ aminobutyric acid (GABA). ${ }^{5}$ These neuroactive steroids have been termed epalons, a shortened form of epiallopregnanolone, and putative epalon receptors may be unique sites on GRC that mediate the effects of neurosteroids on the GABA-gated channel function. Based upon some of the unique characteristics of epalons relative to barbiturates and benzodiazepines, it is plausible that they can be developed into a novel class of therapeutic agents for the treatment of anxiety, epilepsy and insomnia. ${ }^{6}$

From our recent research, we wish to contribute to new ways to improve efficiency and selectivity in oxidation-reduction processes directed towards the synthesis of bioactive steroids, namely neuroactive steroids as epiallopregnanolone and epiallotetrahydrodeoxycorticosterone (epiallotetrahydro-DOC) and aromatase inhibitors as 4-hydroxyandrost-4-ene-3,17-dione and androst-4-ene-3,6,17-trione. 


\section{RESULTS AND DISCUSSION}

\section{Neurosteroids}

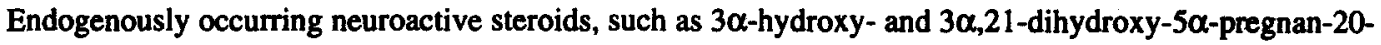
one, commonly named epiallopregnanolone 2 and epiallotetrahydro-DOC 3, have been shown to allosterically regulate the $\mathrm{GABA}_{\mathrm{A}}$ receptor function. $5 \mathrm{c}$

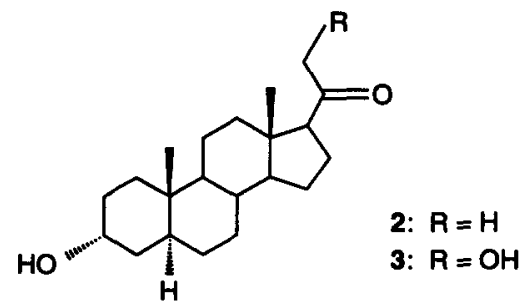

\section{Figure 1}

In an earlier report, ${ }^{7}$ the $3 \alpha$-hydroxy-5 $\alpha$-pregnane moiety in the endogeneous neuroactive steroids 2 and 3 (Figure 1) was obtained in moderate yield (54\%) using the Mitsunobu reaction to accomplish the inversion of configuration at $\mathrm{C}-3$ on the common $3 \beta$-hydroxy-5 $\alpha$-pregnan-20-one. Subsequent 21 -acetoxylation with lead tetraacetate (LTA), followed by hydrolysis under mild basic conditions led to the required $\alpha$-ketol group in $35 \%$ yield for epiallotetrahydro-DOC 3 (Figure 1). Therefore, the 21-hydroxylation is the most detrimental step to the overall yield of such synthetic route.

Despite the relevant properties of the aforementioned steroids, there have been no efforts to improve their synthesis. As a part of our on-going research directed towards the chemical synthesis of steroidal metabolites ${ }^{8}$ we have been investigating alternative methods to achieve the 21-oxidation. Consequently, the following improved synthetic route to epiallotetrahydro-DOC 3 was developed.

The commercially available $5 \alpha$-pregnane-3,20-dione 1 was used as starting material (Scheme 1) and among the methods available to accomplish the reduction of the 3-oxo group we selected the Henbest reduction, $9 \mathrm{a}, \mathrm{b}, \mathrm{c}$ owing to its stereo and chemoselectivity. Under these combined conditions, $9 \mathrm{~b}, \mathrm{c}$ i.e. chloroiridic acid with aqueous isopropanol and hypophosphorous acid, we were able to obtain the $3 \alpha$-axial alcohol 2 in $60 \%$ yield after crystallization from $n$-heptane to remove the epimer with inverted stereochemistry at $\mathrm{C}-17(12 \%)$ found in the crude. The product obtained has showed a high degree of purity $(95-97 \%)$. The $\beta$-side chain at $\mathrm{C}-17$ on compound 2 was ascertained by ${ }^{1} \mathrm{H} \mathrm{nmr}\left(0.60 \mathrm{ppm}\right.$ for $18-\mathrm{H}_{3}$ and $2.53 \mathrm{ppm}$ for $\left.17 \alpha-\mathrm{H}\right)$ and ${ }^{13} \mathrm{C} \mathrm{nmr}(11.18$ ppm for C-18) spectra which were consistent with the published data. ${ }^{10}$ Therefore, the use of hypophosphorous acid led to an improvement of such reductions, allowing yields that are almost the double of the previously reported for identical reactions using trimethyl phosphite (35\%). $9 \mathrm{~b}$ In a similar manner to that described above, $5 \alpha$-androstane-3,17-dione and $5 \alpha$-cholestanone produced exclusively the corresponding $3 \alpha$-hydroxy compounds.9d It should be also emphasized that, in our hands, the Henbest reduction gave more reproducible results than the Mitsunobu reaction. 


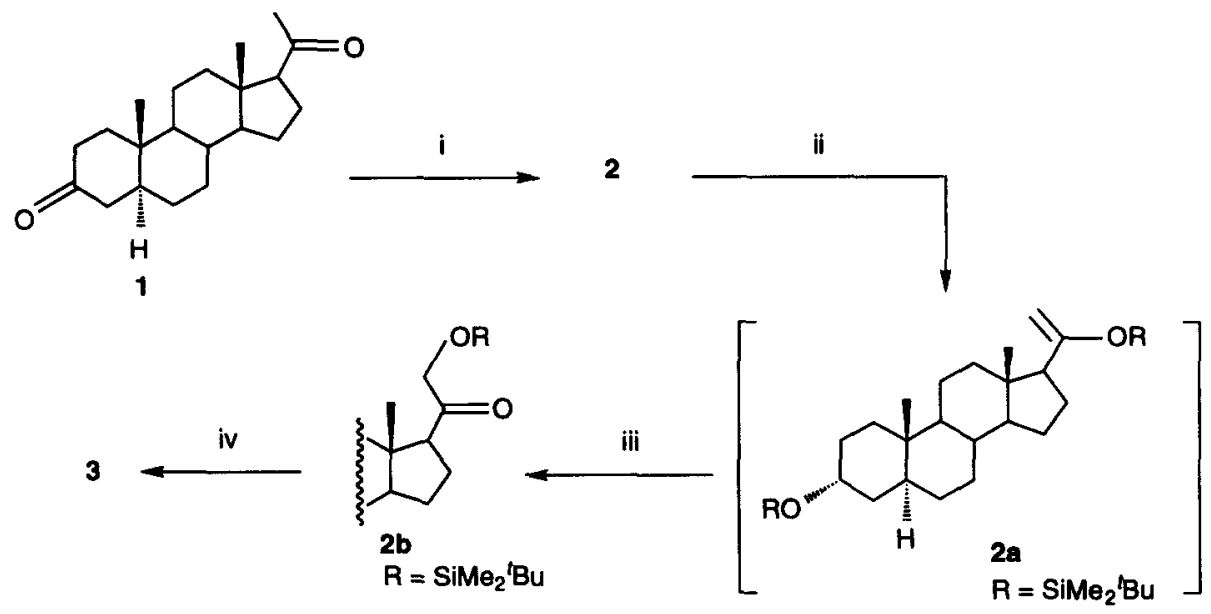

Scheme 1 Reagents and conditions: i, $\mathrm{H}_{2} \mathrm{IrCl}_{6} .6 \mathrm{H}_{2} \mathrm{O}, \mathrm{PrOH}$ aq., $\mathrm{H}_{3} \mathrm{PO}_{3}$, r.t.; ii, TBDMSOTt, $\mathrm{Et}{ }_{3} \mathrm{~N}, \mathrm{CH}_{2} \mathrm{Cl}_{2}, 5^{\circ} \mathrm{C}$; iii, $m$-CPBA, $n-\mathrm{C}_{6} \mathrm{H}_{12},-15^{\circ} \mathrm{C}$ to r.t.; iv, conc. $\mathrm{HCl}: \mathrm{EtOH}$ (2:98).

Different approaches have been used to perform the oxygenation at C-21 on 20 -oxosteroids. ${ }^{11}$ Although the reaction with LTA ${ }^{12}$ is the most often used to indirectly provide this functionalization on steroids, the yields achieved are usually poor to moderate. The enolization of 20-oxosteroids has been investigated recently in our laboratory ${ }^{13}$ and the results obtained led us to forecast the oxidation of a silyl enol ether derivative ${ }^{14}$ as a readily conceivable alternative to the methods commonly used to introduce the 21-hydroxy group. Indeed, the 21oxidation was efficiently accomplished in $71 \%$ yield using the conditions outlined in Scheme 1 . Thus, treatment of 2 with the highly reactive $t$-butyldimethylsilyl triflate (TBDMSOTf ${ }^{13}$ led simultaneously to the 20 -ketone enolization and the $3 \alpha-\mathrm{OH}$ silylation. The progress of the enolization could be followed by ${ }^{1} \mathrm{H} \mathrm{nmr}$, monitoring the $21-\mathrm{H}_{3}$ singlet at $2.11 \mathrm{ppm}$ for compound 2. Subsequent oxidation in situ of $2 \mathrm{a}$ with $m$-chloroperbenzoic acid $(m \text {-CPBA })^{14}$ followed by the spontaneous rearrangement of the unstable 20,21-epoxide smoothly afforded the corresponding silylated $\alpha$-ketol $2 \mathrm{~b}$ from which target epiallotetrahydro-DOC 3 was prepared by hydrolytic cleavage of the silyl ether groups at C-3 and C-21 under mild acidic conditions. The structure of 3 was confirmed by spectroscopic data. Namely, an $\mathrm{AB}$ system was observed at $\delta_{\mathrm{H}} 4.20 \mathrm{ppm}$ and $4.15 \mathrm{ppm}$ for the two protons at C-21 and also the chemical shift for this carbon at $\delta_{C} 69.3 \mathrm{ppm}$ as well as for C-20 $\left(\delta_{\mathrm{C}} 210.4 \mathrm{ppm}\right)$ and C-3 ( $\delta_{\mathrm{C}}$ $66.4 \mathrm{ppm}$ ). The yield of the 21 -hydroxy derivative achieved by this procedure $(71 \%)$ is markedly superior to that obtained by LTA oxidation ( $35 \%){ }^{7}$ Consequently, taking in account such result this oxidative process became a method of choice to perform the 21-hydroxylation on 20-oxosteroids.

The relative convenience of the silyl enol ether peroxidation with $m$-CPBA to achieve the oxidation at $\mathrm{C}-21$ has been reinforced by the application of the described procedure to obtain other important biologically active steroids. ${ }^{15}$ 


\section{Steroid Aromatase Inhibitors}

Among the steroid aromatase inhibitors, 4-hydroxyandrost-4-ene-3,17-dione (4-OHA) 10 (Figure 2), also called formestane, has proved to be very effective in the treatment of advanced breast cancer $16 \mathrm{a}, \mathrm{b}$ and quite recently has found clinical use. ${ }^{17}$

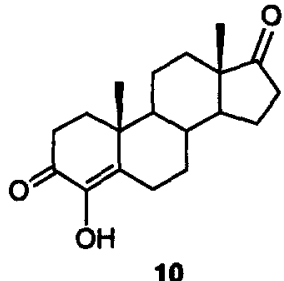

(4-OHA)

Figure 2

Most of the syntheses reported rely upon acid- or base-catalysed opening of a mixture of $4 \alpha, 5 \alpha$ - and $4 \beta, 5 \beta$-epoxides obtained by treatment of androstenedione with alkaline $\mathrm{H}_{2} \mathrm{O}_{2}$, however the overall yields were generally low. ${ }^{18 a, b, c}$ More recently, a moderate yield was reported via alkaline dehydration of 4,5-diols, obtained from androstenedione with osmium tetroxide in the presence of hydrogen peroxide. 19

The establishment of 4-OHA as a drug and the recent upsurge on studies towards the elucidation of the active site of aromatase with 4 -androstenedione analogs, ${ }^{20}$ led us to explore alternative syntheses for this compound (10). Two new strategies have been depicted to circunvent the poor yields reported for the preparation of 4-OHA (Scheme 2). One of these, already reported, ${ }^{21}$ uses $5 \alpha$-androst-3-en-17-one 4 as starting material and through a two-step oxidative route followed by base-catalysed isomerization leads to 4-OHA, 10 (route A).

We describe herewith another strategy (route B), which uses the readily available testosterone 6 as starting material. Under the hydroboration/oxidation conditions described for cholest-4-en-3-one, ${ }^{22}$ reduction at C-3 preceeds the formation of the $3 \beta, 4 \alpha$-dihydroxy moiety. When the reaction was quenched after 2 hours the intermediate compound 7 was the only compound isolated and the allylic alcohol moiety was detected by ${ }^{1} \mathrm{H}$ nmr (4.14 ppm for 4-H and $5.28 \mathrm{ppm}$ for $3 \alpha-\mathrm{H})$ and ${ }^{13} \mathrm{C} \mathrm{nmr}(67.8 \mathrm{ppm}$ for $\mathrm{C}-3$ and $123.6 \mathrm{ppm}$ for $\mathrm{C}-4$ and 147.3 ppm for C-5) spectra which were consistent with the published data.23a,b,c Further, using Swern type conditions, DMSO-trifluoroacetic anhydride, $3 \beta, 4 \alpha, 17 \beta$-triol 8 was quantitatively oxidized to afford the kinetic diosphenol 3-hydroxy-5 $\alpha$-androst-2-ene-4,17-dione 9 which by base-catalysed isomerization led to the desired thermodynamic diosphenol, 4-OHA 10 (Scheme 2).

The reagents used in both short convergent routes are non-toxic and moderately inexpensive, and most of the reactions are fast and high yielding. Nevertheless, the low cost of the readily available starting material, testosterone 6, used in route B renders this approach very competitive to prepare 4-OHA. 


\section{Bouna}

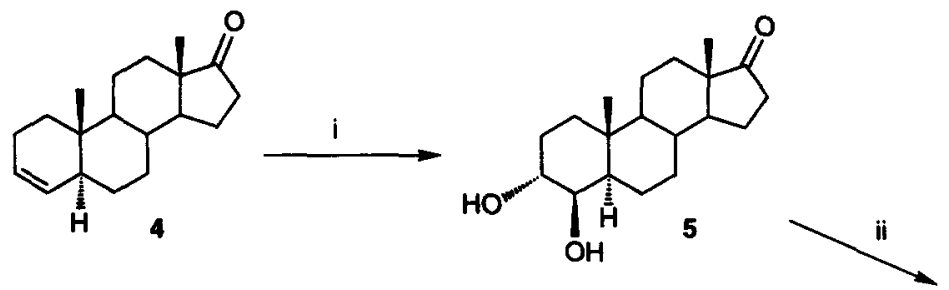

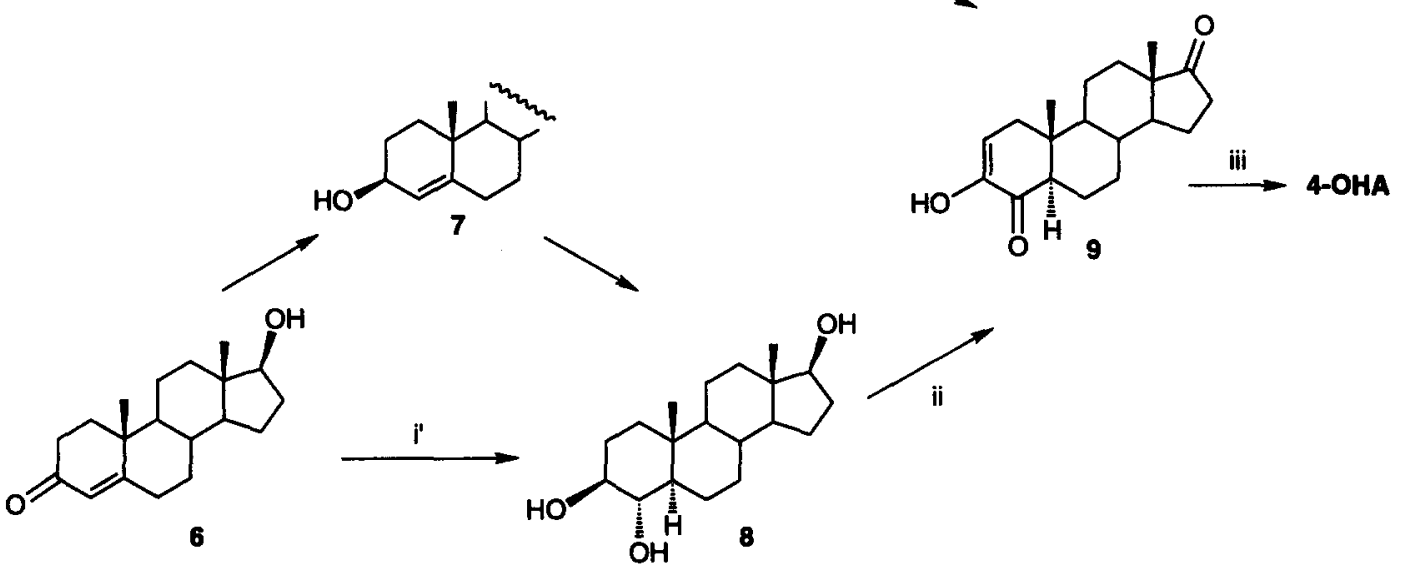

Boute $\mathrm{B}$

Scheme 2 Reagents and conditions: $\mathrm{i}, \mathrm{H}_{2} \mathrm{O}_{2}, \mathrm{HCO}_{2} \mathrm{H}$, r.t., $1 \mathrm{~h}$; i', BF 3 -etherate, $\mathrm{NaBH}_{4}$, Diglyme, THF, r.t., 24h then $\mathrm{H}_{2} \mathrm{O}_{2}, \mathrm{KOH}$, reflux, $5^{\prime}$; ii, DMSO, TFAA, $-60^{\circ} \mathrm{C}$, 3h then $\mathrm{Et}_{3} \mathrm{~N},-60^{\circ} \mathrm{C}$ 15'; iii, $\mathrm{Na}$, MeOH, r.t., 1 h.

Another aromatase inhibitor, the androst-4-ene-3,6,17-trione 12 (Figure 3) is an important $\Delta^{4}$-3,6-dioxosteroid with general biological interest. ${ }^{24}$ Most of the processes mentioned in the literature used $\mathrm{Cr}(\mathrm{VI})$ reagents under drastic conditions to oxidize $\Delta^{5}-3 \beta$-hydroxy groups. ${ }^{25}$ Some years ago we developed a mild method for this transformation with tetra- $n$-propylammonium perruthenate (TPAP) and 4-methylmorpholine $\mathrm{N}$-oxide as cooxidant under ultrasonic irradiation. ${ }^{26}$ However the considerable expense of using TPAP led us to search for other processes. Recently, the use of the milder pyridinium chlorochromate (PCC) to perform this type of transformations has been reported, although large amounts of the reagent are required. 27<smiles>C[C@]12CCC3C(CC(=O)C4=CC(=O)CC[C@@]43C)C1CCC2=O</smiles>

12

Figure 3 
The use of ultrasound in organic reactions has been widely applied in synthesis ${ }^{28}$ and our previous experience ${ }^{29}$ encouraged us to utilize this technology in our process. Moreover, the use of PCC on clays under ultrasonic irradiation allowed us to benefit from the use of supported reagents, especially to afford products free from contamination with by-products. ${ }^{30}$

When the dehydroepiandrosterone 11 was treated with 4 mmoles of PCC on montmorillonite K10 under sonochemical conditions, a fast reaction led to the aromatase inhibitor androst-4-ene-3,6,17-trione 12, in high yield (Scheme 3 and Table 1).<smiles>C[C@]12CCC3C(CC=C4C[C@H](O)CC[C@@]43C)C1CCC2=O</smiles>

11

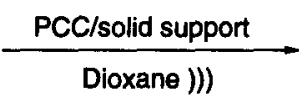

Dioxane ))

Scheme 3

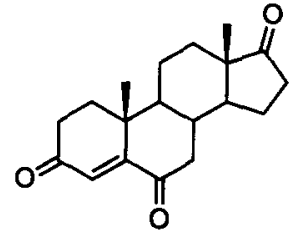

12

Table 1. Oxidation of Dehydroepiandrosterone with PCC on montmorillonite K10

\begin{tabular}{ccccc} 
Entries & $\begin{array}{c}\text { PCCa } \\
\text { mmoles }\end{array}$ & $\begin{array}{c}\text { Solid } \\
\text { support }\end{array}$ & Product & $\begin{array}{c}\text { Yield }^{\mathrm{b}} \\
(\%)\end{array}$ \\
\hline 1 & 4 & $\mathrm{~K} 10$ & $\mathbf{1 2}+\Delta^{5}$-3-ketone & $<20$ \\
2 & 4 & $-/ /)))$ & 12 & 86 \\
3 & 4 & $\mathrm{~K} 10 /)))$ & 12 & 90 \\
\hline
\end{tabular}

${ }^{a}$ The reactions were performed with 1 mmole of substrate. ${ }_{\text {Reaction time }} 45$ minutes.

The effect of ultrasonic irradiation on the reaction performed allows us to conclude that ultrasound promotes a drastic reduction on the amount of PCC used when compared with similar transformations previously reported. ${ }^{27}$ In addition, a positive effect on the rate and the yield of the reaction has been observed (Entries 2 and 3,Table 1). Furthermore, the use of solid supports gives an easier work-up. Under the described conditions, similar results have been found for pregnenolone and cholesterol, allowing the synthesis of the corresponding $\Delta^{4}$. 3,6-dioxosteroids with improved efficiency.

In summary, a new methodology has allowed a significant improvement for each one of the reactions sequence leading to the $3 \alpha$ - and 21-hydroxylations required to synthesize the neurosteroids epiallopregnanolone 2 and epiallotetrahydro-DOC 3. The Henbest reduction of the C-3 unhindered ketone is reproducible and the preparation of a silyl enol ether, and its oxidation in situ with $m$-CPBA have allowed the 21-hydroxylation in better overall yield. Moreover, a new short synthesis of the aromatase inhibitor, 4-OHA 10, has been achieved with the advantage of using testosterone 6 as a low cost starting material, besides most of the reactions being high yielding. In addition, the combination of ultrasound with clay supported PCC has been shown to be very beneficial in terms of reaction rate, reagent economy and work-up simplification to prepare the aromatase inhibitor, androst-4-ene-3,6,17-trione 12. 


\section{EXPERIMENTAL SECTION}

$5 \alpha$-Pregnane-3,20-dione and dehydroepiandrosterone were commercially available from Sigma and testosterone from Steroid Cologno Monzese. TBDMSOTf (98\%) and $m$-CPBA (80-90\%) were commercially obtained from Aldrich Chemie. Reaction solvents were dried and distilled before use according to standard procedures. Melting points were determined with a Reichert microscope apparatus and were uncorrected. Unless otherwise stated i.r. spectra refer to $\mathrm{KBr}$ pellets. ${ }^{1} \mathrm{H} \mathrm{nmr}$ and ${ }^{13} \mathrm{C} \mathrm{nmr}$ were performed in $\mathrm{CDCl}_{3}$, unless otherwise indicated, with $\mathrm{Me}_{4} \mathrm{Si}$ as internal standard. $J$ values are given in $\mathrm{Hz}$. For TLC analyses Kieselgel 60 $\mathrm{HF}_{254} / \mathrm{kieselgel} 60 \mathrm{G}$ was used. The Henbest reduction was performed according to the conditions reported in the literature. ${ }^{\mathrm{gb}, \mathrm{c}}$

General Procedure for 21-Hydroxylation: $3 \alpha$-Hydroxy-20-oxopregnane $2(250 \mathrm{mg}, 0.785 \mathrm{mmol}$ ) was dissolved in $\mathrm{CH}_{2} \mathrm{Cl}_{2}(2 \mathrm{ml})$. This solution was stirred at room temperature and then triethylamine $(2.0 \mathrm{ml})$ immediately followed by TBDMSOTf $(2 \mathrm{ml}, 8.53 \mathrm{mmol})$ were added dropwise. ${ }^{13}$ The reaction was followed by ${ }^{1} \mathrm{H} \mathrm{nmr}$ recording the spectra between 1.5 and $2.5 \mathrm{ppm}$. After 1 hour the $21-\mathrm{H}_{3}$ singlet, at $2.11 \mathrm{ppm}$, of the starting material 2 was absent. Subsequently, the reaction mixture was diluted with $\mathrm{CH}_{2} \mathrm{Cl}_{2}(20 \mathrm{ml})$, extracted with $10 \% \mathrm{NaHCO}_{3}(2 \times 10 \mathrm{ml})$ and the organic phase was dried over anhydrous $\mathrm{MgSO}_{4}$. Filtration and removal of the solvent under reduced pressure afforded the crude product which was dissolved in anhydrous ether. Subsequent to filtration and evaporation of the solvent under reduced pressure, the 20-(t-butyldimethylsilyl)oxy$3 \alpha$-hydroxypregn-20-ene $2 \mathrm{a}$ was obtained. A solution of this enol silyl ether $2 \mathrm{a}$ in $n$-hexane ( $7.0 \mathrm{ml}$ ) was added dropwise to a suspension of $m$-CPBA $(260 \mathrm{mg}, 1.28 \mathrm{mmol})$ in $n$-hexane $(20 \mathrm{ml})$ at $-15^{\circ} \mathrm{C}$, under magnetic stirring. The mixture was kept at $-15^{\circ} \mathrm{C}$ for $10 \mathrm{~min}$ and then was allowed to warm up to room temperature. The reaction was followed by TLC (ether/toluene, 2:8). After 4 hours the solvent was evaporated under reduced pressure. The solid obtained was dissolved in pentane and the residual $\mathrm{m}$-CPBA, insoluble in this solvent, was removed by filtration. The filtrate was washed with $10 \% \mathrm{NaHCO}_{3}(3 \times 25 \mathrm{ml})$ and $\mathrm{H}_{2} \mathrm{O}(3 \times 25 \mathrm{ml})$ and the organic phase was dried over anhydrous $\mathrm{MgSO}_{4}$. The crude obtained $(530 \mathrm{mg})$ by evaporation of the solvent under reduced pressure was immediatly dissolved in a $2 \%$ conc. $\mathrm{HCl} / \mathrm{EtOH}$ solution $(20 \mathrm{ml})$ and the reaction was stirred at room temperature for 24 hours. Then was diluted with cold $\mathrm{H}_{2} \mathrm{O}$, neutralized with $10 \% \mathrm{NaHCO}_{3}$ and extracted with $\mathrm{CH}_{2} \mathrm{Cl}_{2}(3 \times 150 \mathrm{ml})$. The organic phase was successively washed with $10 \% \mathrm{NaHCO}_{3}(3 \times 150 \mathrm{~mL})$ and $\mathrm{H}_{2} \mathrm{O}(2 \times 100 \mathrm{ml})$ and dried over anhydrous $\mathrm{MgSO}_{4}$. Evaporation of the solvent under reduced pressure afforded, after crystallization, the $3 \alpha, 21$-dihydroxy-20-oxopregnane $3(185 \mathrm{mg}, 71 \%)$ : $\mathrm{mp} 165^{\circ} \mathrm{C}$ (acetone / ethanol), [lit. ${ }^{31} 163-166^{\circ} \mathrm{C}$ (acetone)]; $v_{\max } 3350(\mathrm{OH}), 1710(\mathrm{CO}), 1375 \mathrm{~cm}^{-1} ;{ }^{1} \mathrm{H} \mathrm{nmr}(500 \mathrm{MHz}) \delta 0.63(3 \mathrm{H}$, s, $\left.18-\mathrm{H}_{3}\right), 0.78\left(3 \mathrm{H}, \mathrm{s}, 19-\mathrm{H}_{3}\right), 2.45(1 \mathrm{H}, \mathrm{t}, J 9,17 \alpha-\mathrm{H}), 4.05(1 \mathrm{H}, \mathrm{t}, J 2.5,3 \beta-\mathrm{H}), 4.18\left(2 \mathrm{H}, \mathrm{q}_{\mathrm{AB}}, \delta_{\mathrm{A}}=4.20\right.$, $\left.\delta_{\mathrm{B}}=4.15, J_{\mathrm{AB}} 18.5,21-\mathrm{H}_{2}\right) ;{ }^{13} \mathrm{C}$ NMR $\delta 11.13(\mathrm{C}-18), 13.5(\mathrm{C}-19), 66.4(\mathrm{C}-3), 69.3(\mathrm{C}-21), 210.4(\mathrm{C}-20)$; $\mathrm{M}^{+}$(EI) 334.493 .

\section{Synthesis of $5 \alpha$-androstane-3 $\beta, 4 \alpha, 17 \beta$-triol 8}

A stirred solution of testosterone $6(500 \mathrm{mg} ; 1.73 \mathrm{mmol})$ in dry tetrahydrofuran $(17 \mathrm{ml})$ was treated with an excess of diborane at $0{ }^{\circ} \mathrm{C}$ under dry nitrogen for $6 \mathrm{~h}$. The gas was generated externally 32 by slow dropwise addition of a $0.2 \mathrm{M}$ solution of sodium borohydride in diglyme $(31.2 \mathrm{ml})$ to a cool $\left(0^{\circ} \mathrm{C}\right)$ and stirred boron trifluoride etheratediglyme solution ( $1.2 \mathrm{ml} ; 12.74 \mathrm{mmol})$ and then passed into the steroid-tetrahydrofuran solution by applying a 
slight flow of dry nitrogen through the generator. The generator was then disconnected from the hydroboration flask, the temperature was raised to $20^{\circ} \mathrm{C}$ and the solution was stirred for a further $18 \mathrm{~h}$ (TLC control) after which the mixture was carefully diluted with water $(10 \mathrm{ml})$. Potassium hydroxide ( $5 \%$ methanol solution; $7 \mathrm{ml})$ was then added to the mixture followed by dropwise addition of hydrogen peroxide $(30 \% ; 1.3 \mathrm{ml}$ ) and the mixture was heated under reflux for $5 \mathrm{~min}$. The solution was neutralized with a $10 \%$ aq. $\mathrm{HCl}$, poured into stirred cold water (75 $\mathrm{ml}$ ) and the insoluble solid was filtered and dried to yield the pure title compound 8 ( $231 \mathrm{mg} ; 43 \%)$. The aqueous phase was further extracted with dichloromethane, the extract was washed with aq. $\mathrm{NaHCO}_{3}$ and water, dried $\left(\mathrm{MgSO}_{4}\right)$ and evaporated to dryness to give a solid residue which after trituration with ethyl acetate followed by filtration yielded an additional portion (67 mg; $12 \%$ ) of the pure compound $833 \mathrm{a}, \mathrm{b}, \mathrm{c,d}, \delta_{\mathrm{H}}\left(500 \mathrm{MHz} ; \mathrm{Py}_{\mathrm{d} \sigma}\right) 0.90$ (3H, s, 18- $\left.\mathrm{H}_{3}\right), 0.99$ (3H, s, 19- $\left.\mathrm{H}_{3}\right), 3.70$ (1H, dd, $\left.J_{17 \alpha, 16 \alpha} 9.2, J_{17 \alpha, 16 \beta} 9.2,17 \alpha-\mathrm{H}\right), 3.82$ (1H, ddd, $J_{3 \alpha, 2 \beta}$ 11.6, $\left.J_{3 \alpha, 4 \beta} 8.6, J_{3 \alpha, 2 \alpha} 5.2,3 \alpha-\mathrm{H}\right), 3.90\left(1 \mathrm{H}, \mathrm{dd}, J_{4 \beta, 5 \alpha} 8.6, J_{4 \beta, 3 \alpha} 8.6,4 \beta-\mathrm{H}\right), 5.01-6.05(3 \mathrm{H}, 3-\mathrm{OH}, 4-\mathrm{OH}$ and 17-OH, disappeared with $\left.\mathrm{D}_{2} \mathrm{O}\right)$; ${ }^{\delta_{\mathrm{C}}}\left(125 \mathrm{MHz}, \mathrm{Py}_{\mathrm{d} 6}\right) 11.9(\mathrm{C}-18), 13.9(\mathrm{C}-19), 75.5^{34}(\mathrm{C}-3), 76.7^{34}(\mathrm{C}-4)$, 81.4(C-17).

\section{Synthesis of 3-Hydroxy-5 $\alpha$-androst-2-ene-4,17-dione 9}

To a stirred and cooled $\left(-60^{\circ} \mathrm{C}\right)$ mixture of dimethylsulfoxide $(0.23 \mathrm{ml} ; 3.24 \mathrm{mmol})$ in dichloromethane $(9 \mathrm{ml})$ under nitrogen, trifluoroacetic anhydride $(0.41 \mathrm{ml} ; 2.95 \mathrm{mmol})$ was added dropwise. After $10 \mathrm{~min}$ a solution of the triol 8 (155 $\mathrm{mg} ; 0.50$ mmoles) in a mixture of dichloromethane and dimethylsulfoxide $(2 \mathrm{ml})$ was added and stirred until the steroid was consumed ( $3 \mathrm{~h}$, TLC control). Triethylamine $(1.0 \mathrm{ml} ; 7.17 \mathrm{mmol})$ was then added and after $15 \mathrm{~min}$. at $-60^{\circ} \mathrm{C}$ the temperature was raised to $5^{\circ} \mathrm{C}$. The solution was poured into $2 \mathrm{~N}$ hydrochloric acid (40 $\mathrm{ml}$ ) and extracted with dichloromethane. The extract was washed with aq. $\mathrm{NaHCO}_{3}$ and water, dried $\left(\mathrm{MgSO}_{4}\right)$ and evaporated to dryness yielding the crude diosphenol 921 (149 mg; 98\%) as the only detected product. This pale yellow solid could not be crystallized, ${ }^{35}$ and an analytical sample was purified by column chromatography [silica gel; ethyl acetate-light petroleum (bp 60-80 ${ }^{\circ} \mathrm{C}$ ) (1:1)]; (Found: $\mathrm{C}, 75.46 ; \mathrm{H}, 8.97 . \mathrm{C}_{19} \mathrm{H}_{26} \mathrm{O}_{3}$ requires C,75.46; H, 8.67\%); $v_{\max } 3400(\mathrm{OH}), 1743(\mathrm{C}=\mathrm{O}), 1675 \mathrm{~cm}^{-1}(\mathrm{C}=\mathrm{O}) ; \delta_{\mathrm{H}}(500 \mathrm{MHz}) 0.88\left(3 \mathrm{H}, \mathrm{s}, 18-\mathrm{H}_{3}\right), 0.93$ $\left(3 \mathrm{H}, \mathrm{s}, 19-\mathrm{H}_{3}\right), 5.85\left(1 \mathrm{H}, \mathrm{s}, 3-\mathrm{OH}\right.$, disappeared with $\left.\mathrm{D}_{2} \mathrm{O}\right), 5.96\left(1 \mathrm{H}, \mathrm{dd}, J_{2,1} 3.0, J_{2,1} 7.0,2-\mathrm{H}\right) ; \delta_{\mathrm{C}}(50.3$ MHz) 13.2 (C-18), 13.7 (C-19), 113.9 (C-2), 145.9 (C-3), 196.8 (C-4) 220.7 (C-17).

\section{Synthesis of 4-Hydroxyandrost-4-ene-3,17-dione 10}

To a stirred and cooled $\left(0^{\circ} \mathrm{C}\right)$ solution of $9(60 \mathrm{mg} ; 0.2 \mathrm{mmol})$ in methanol $(3 \mathrm{ml})$ under nitrogen, sodium metal (50 mg; $2.2 \mathrm{mmol}$ ) was added. After $\mathrm{lh}$ at room temperature the solution was neutralized with $10 \% \mathrm{aq} . \mathrm{HCl}$ and the usual work-up was followed. The residue was purified by flash chromatography [silica gel; diethyl ethercarbon tetrachloride (1:1)] to give the title compound 10 (48 mg, 80\%) as pure colourless needles, mp 202-203 ${ }^{\circ} \mathrm{C}$ (ethyl acetate) [lit. ${ }^{18 \mathrm{c}} 201-203^{\circ} \mathrm{C}$ ); $v_{\max } 3415,3390(\mathrm{OH}), 1743(\mathrm{C}=\mathrm{O}), 1672(\mathrm{C}=0), 1636 \mathrm{~cm}^{-1}(\mathrm{C}=\mathrm{C})$; $\delta_{\mathrm{H}}(500 \mathrm{MHz}) 0.92\left(3 \mathrm{H}, \mathrm{s}, 18-\mathrm{H}_{3}\right), 1.20\left(3 \mathrm{H}, \mathrm{s}, 19-\mathrm{H}_{3}\right), 3.069(1 \mathrm{H}, \mathrm{m}, 6 \alpha-\mathrm{H}), 6.16(1 \mathrm{H}, \mathrm{s}, 4-\mathrm{OH}$, disappeared with $\mathrm{D}_{2} \mathrm{O}$ ); $\delta_{\mathrm{C}}(125 \mathrm{MHz}) 13.7(\mathrm{C}-18), 17.1$ (C-19), $139.2(\mathrm{C}-5), 141.3(\mathrm{C}-4), 193.5(\mathrm{C}-3) 220.7$ (C-17).

\section{General Procedure for $\Delta^{\mathbf{4}} \mathbf{- 3 , 6}$-diketones}

PCC (860mg; 4 mmoles) and montmorillonite $K 10(500 \mathrm{mg})$ were ground into a fine powder and the mixture was added to a flask containing DHA $11(288,4 \mathrm{mg} ; 1 \mathrm{mmole})$ in dioxane $(20 \mathrm{ml})$. The mixture was submitted to ultrasonic irradiation with an immersion probe system (Sonics \& Materials Inc, Mod. V.C. $600 \mathrm{~W}, 20 \mathrm{KHz}, 1 / 2$ 
inch probe $\left.80 \mathrm{Wcm}^{-2}\right)$ and after 45 minutes, TLC analysis (1:1, EtOAc/petroleum ether $\left.40-60^{\circ} \mathrm{C}\right)$ indicated the full conversion of $\Delta^{5}-3 \beta$-hydroxy steroid into $\Delta^{4}-3,6$-diketone. The reaction solution was diluted with $\mathrm{Et}_{2} \mathrm{O}$ and filtered through Celite. Excess solvent was removed under reduced pressure to afford a yellow oil which was chromatographed on silica gel, 70-230 mesh, (1:1, EtOAc/petroleum ether $\left.40-60^{\circ} \mathrm{C}\right)$. The organic phase was then sucessively washed with $10 \%$ aqueous sodium bicarbonate $(2 \times 50 \mathrm{ml})$, water $(2 \times 100 \mathrm{ml})$, and dried $\left(\mathrm{Na}_{2} \mathrm{SO}_{4}\right)$. Removal of the drying agent and solvent resulted in a solid which after crystallization (isopropyl ether) gave the product 1225b,26 (367mg; 89\%). mp 220-222 ${ }^{\circ} \mathrm{C}$ (isopropyl ether) [lit. $25 \mathrm{~b} 222-227^{\circ} \mathrm{C}$ ], $\mathrm{v}_{\max } 2956,1737,1686$, $1600(\mathrm{C}=\mathrm{C}), \mathrm{cm}^{-1} . \delta_{\mathrm{H}}(300 \mathrm{MHz}) 0.87\left(3 \mathrm{H}, \mathrm{s}, 18-\mathrm{H}_{3}\right), 1.14\left(3 \mathrm{H}, \mathrm{s}, 19-\mathrm{H}_{3}\right), 6,13(1-\mathrm{H}, \mathrm{s}, 4-\mathrm{H}) . \delta_{\mathrm{C}}(75 \mathrm{MHz})$ 125.75 (C-4), 160.05 (C-5), 198.95 (C-3), 201.02 (C-6), 219.09 (C-17) .

Acknowledgement: We thank the former Junta Nacional de Investigação Científica (JNICT) and Fundação para a Ciência e Tecnologia (FCT), PRAXIS XXI and PRODEP Programs for their past and present financial contributions and the award of fellowships.

\section{REFERENCES AND NOTES}

1. (a) Zeelen, F. J. Medicinal Chemistry of Steroids; Elsevier: Amsterdam 1990. (b) Blickenstaff, R. T. Antitumor Steroids; Academic Press: New York, 1992.

2. Lewis, D. F. V. Cytochromes P450-Structure, Function and Mechanism, Taylor \& Francis: London 1996.

3. Zeelen, F. J.: Medicinal Chemistry of Steroids: Recent Developments. In Advances in Drug Research, Testa, B. Eds.; Academic Press: London, 1992, Vol. 22, pp. 149-189.

4. Johannessen, D. C. and Lønning, P. E. Drugs \& Aging, 1992, 2, 530-545.

5. (a) H. Yuefei; F. Zorumski ; D. F. Covey, J. Med. Chem., 1993, 36, 3956-3967. (b) Lambert, J. L.; Belelli, D.; Venning, C. H.; Peters, J. A. Trends Pharm. Sc. 1995, 16, 295-303. (c) Finn, D. A.; Gee, K. W. J. Pharmacol. Exp. Ther. 1993, 265, 1374-1379. (d) Rupprecht, R.; Hauser, C.A.; Trapp, T.; Holsboer, F. J. Steroid Biochem. Mol. Biol., 1996, 56, 163-168.

6. Gee, K. W.; McCauley, L. D.; Lan, N. C. Crit. Rev. Neurobiol., 1995, 9 (2-3), 207-227.

7. Purdy, P. H.; Morrow, A. L.; Blinn, J. R.; Paul, S. M. J. Med. Chem., 1990, 33, 1572-1581 and references cited therein.

8. Moreno, M. J. S. M.; Sá e Melo, M. L.; Campos Neves, A. S. Tetrahedron Lett, 1993, 353-356; Moreno, M. J. S. M.; Sá e Melo, M. L.; Campos Neves, A. S. Synlet, 1994, 651-652.

9. (a) Haddad, Y. M. Y.; Henbest, H. B.; Husbands, J.; Mitchell, T. R. B. Proc. Chem. Soc., 1964, 361. (b) Browne, P. A.; Kirk, D. N.J. Chem. Soc. C, 1969, 1653-1659. (c) Henbest, H. B.; Mitchell, T. R. B. J. Chem. Soc. C, 1970, 785-790. (d) Pereira Costa, S. et al.; unpublished results.

10. Pouchert, C. J.; Behnke, J. The Aldrich Library of ${ }^{13} \mathrm{C}$ and ${ }^{\prime} \mathrm{H}$ FT NMR Spectra, Aldrich Chemical Company Ed.; Vol. I., 576.

11. (a) Waring, A. J. In Comprehensive Organic Chemistry; Barton, D.; Ollis, W. D. Eds.; Pergamon Press: Oxford, 1979, p-1065; (b) Kamernitzky, A. V.; Turuta, A. M. ; Fadieva, T. M. ; Istomina, Z. I. Synthesis 1985, 326-328. (c) Moriarty, R. M.; Hou, K. C. Tetrahedron Lett. 1984, 25, 691-694, (d) Vedejs, E., Engler, D. A.; Telschow, J. E. J. Org. Chem 1978, 43, 188-196. (e) McCormick, J. P.; Tomasik, W.; Johnson, M. W. Tetrahedron Lett. 1981, 607.

12. Cocker, J. D.; Henbest, H. B.; Phillips, G. H.; Slater, G. P.; Tomas, D. A. J. Chem. Soc. 1965, 6. 
13. Moreno, M. J. S. M.; Martins, R. M. L. M.; Sá e Melo, M. L.; Campos Neves, A. S. Chem. Letters, 1997, 529-530 and references cited therein.

14. (a) Rubottom, G. M.; Vasquez, M. A.; Pelegrina, D. R. Tetrahedron Lett. 1974, 4319-4322. (b) Rubottom, G. M.; Gruber, J. M.; Juve, H. D.; Charleson, D. A. Org. Synthesis 1986, 64, 118-125.

15. Moreno, M. J. S. M. et al., results to be published.

16. (a) Hoffken, K.; Jonat, W.; Possinger, K.; Kolbel, M.; Kunz, T. H.; Wagner, H.; Becher, R.; Callies, R.; Friederich, P.; Willmanns, W.; Maass, H.; Schmidt, C. G. J. Clin. Oncology 1990, 8, 875. (b) Pickles, T.; Perry, L.; Murray P. and Plowman, P. Br. J. Cancer 1990, 62, 309.

17. Brodie, A. M. J. Steroid. Biochem. Mol. Biol. 1994, 49, 281-287

18. (a) Marsh, D. A.; Brodie, H. J.; Garrett, W.; Tsai-Morris C. H. and Brodie, A. M. H. J. Med. Chem. 1985, 28, 788-795. (b) Bednarski, P. J. and Nelson, S. D. J. Med. Chem. 1989, 32, 203-213. (c) Mann, J. and Pietrzak, B. J. Chem. Soc. Perkin Trans. I, 1983, 1I, 2681-2685.

19. Ciattini, P. G.; Morera, E. and Ortar, G. Synth. Commun., 1992, 22, 1949-1952.

20. Liu, X. P.; Lambert D. M. and Abul-Hajj, Y. J. J. Med. Chem. 1995, 38, 4135-4138.

21. Tavares da Silva, E. J.; Sá e Melo, M. L. and Campos Neves, A. S. J. Chem. Soc. Perkin Trans. 1 1996, 1649-1650.

22. Caglioti, L. and Cainelli, G. Rend. Accad. Lincei 1960, 29, 555-561.

23. (a) Cambie, R. C.; Rutledge, P. S.; Scott, D. W. and Woodgate, P. D. Aust. J. Chem., 1979, 32, 695698. (b) Mori, M.; Ikegami, S. and Tamaoki, B. Steroids, 1979, 33, 467-477. (c) Parish, E. J. and Scott, A. D. J. Org. Chem., 1983, 48, 4766-4768.

24. Numazawa, M.; Tsuji, M.; Mutsumi, A. J. Steroid Biochem., 1987, 28, (3), 337-344.

25. (a) Fieser, L.F.Organic Synthesis, New York:Wiley, 1963, Collect, Vol 4, 195-201. (b) Solaja, B. A.; Milic, D. R.; Dosen-Micovic, L. I. Steroids, 1994, 59, 330-334 and references cited therein.

26. Miranda Moreno, M. J. S.; Sá e Melo, M. L.; Campos Neves, A. S.Tetrahedron Lett., 1991, 32 (27), 3201-3204.

27. (a) Parish, E. J.; Kizito, S. A.; Peng, J.; Heidepriem, R. W.; Livant, P. Chem.Phys.Lipids, 1995, 76, 129-133.(b) Li, Sheng-Hui; Li, Tong-Shuang Li Steroids, 1998, 63, 76-79 and references cited therein.

28. (a) Mason, T. J. Chem.Soc.Rev. 1997, 26, 443-451. (b) Mason,T. J.; Luche, J. L. Ultrasound as a New Tool for Synthetic Chemists. In Chemistry Under Extreme or Non-Classical Conditions; Van Eldik, R.; Hubbard, C. D., Eds, John Wiley \& Sons, Inc. and Spektrum Akademischer Verlag, 1997, 317-380.

29. Sá e Melo, M.L.; Moreno, M.J.S.M.; Pereira da Costa, S.C.; Salvador, J.A.R.; Campos Neves, A.S. Ultrasonics Sonochemistry, 1994, 1 (1), S37-S40 and references cited therein.

30. Clark, J. H.; Macquarrie, D. J. Chem.Soc.Rev., 1996, 303-310.

31. Harnik, M. Steroids, 1964, 3, 359-379.

32. Zweifel, G. and Brown, H. C.: Hydration of Olefins, Dienes and Acetylenes via Hydroboration. In Organic Reactions; Cope A. C., Eds.; Wiley: New York, 1965; Vol. 13, pp. 1-54.

33. (a) Nakata, H. Bull. Chem. Soc. Jpn., 1965, 38, 378-380. (b) Tömörkéni, E.; Tóth, G.; Horváth, G.; and Büki, K. G.; Acta Chim. Acad. Sci. Hung., 1975, 87, 409-418. (c) Cambie, R. C.; Rutledge, P. S.; Scott, D. W. and Woodgate, P. D. Aust. J. Chem., 1979, 32, 695-698. (d) Hanson, J. R.; Hitchcock, P. B.; Liman, M. D. and Nagaratnam, S. J. Chem. Soc., Perkin Trans. I, 1995, 2183-2187.

34. Assignments may be exchanged.

35. Attempts to recrystallise this compound were unsuccessful due to its conversion in 4-OHA. 